\title{
REVISED Periprosthetic bone loss: diagnostic and therapeutic
}

\section{approaches [version 2; peer review: 2 approved, 1 approved}

\section{with reservations]}

\author{
Loredana Cavalli, Maria Luisa Brandi
}

Department of Surgery and Translational Medicine, University of Florence, Florence, 50139, Italy

\author{
V2 First published: $05 \operatorname{Dec} 2013, \mathbf{2 : 2 6 6}$ \\ https://doi.org/10.12688/f1000research.2-266.v1 \\ Latest published: 17 Jun 2014, 2:266 \\ https://doi.org/10.12688/f1000research.2-266.v2
}

\section{Open Peer Review

$\begin{array}{rrr}\text { Approval Status } & \\ 1 & 2 & 3\end{array}$ \\ version 2 \\ (revision) \\ 17 Jun 2014 \\ version 1 \\ 05 Dec 2013

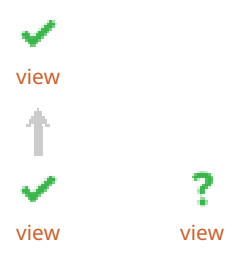

1. Jason K.F. Wong, University of Manchester,

Manchester, UK

\section{Javad Parvizi, Thomas Jefferson University}

Hospital, Philadelphia, PA, USA

\section{P Edward Purdue, Hospital for Special \\ Surgery, New York, USA}

Any reports and responses or comments on the article can be found at the end of the article.

\section{Keywords}

periprosthetic bone loss, osteolysis, stress shielding , subsidence, BMD , DXA , BMA , implant , arthroplasty , bisphosphonate, strontium ranelate 
Corresponding author: Maria Luisa Brandi (m.brandi@dmi.unifi.it)

Competing interests: No competing interests were disclosed.

Grant information: The author(s) declared that no grants were involved in supporting this work.

Copyright: @ 2014 Cavalli L and Brandi ML. This is an open access article distributed under the terms of the Creative Commons Attribution License, which permits unrestricted use, distribution, and reproduction in any medium, provided the original work is properly cited.

How to cite this article: Cavalli $L$ and Brandi ML. Periprosthetic bone loss: diagnostic and therapeutic approaches [version 2; peer review: 2 approved, 1 approved with reservations] F1000Research 2014, 2:266 https://doi.org/10.12688/f1000research.2-266.v2

First published: 05 Dec 2013, 2:266 https://doi.org/10.12688/f1000research.2-266.v1 


\section{REVISED Amendments from Version 1}

At the end of the paragraph Imaging techniques for the evaluation etc., before the last sentence, we added: "Although not currently widespread, except in few research centers specialized in bone diseases, the employment of BMA..."

We added a brief paragraph about the metal subtraction option in X-ray CT imaging as it represents a real possibility to correct artifacts. Some references were added and others changed.

Citing the studies on OPG and RANK-Fc, the first molecular strategy in this field, we added the sentence "but the successful preclinical findings, i.e. the ability to prevent and reverse wear debris-induced osteolysis, have not been confirmed by clinical trials".

Regarding Strontium Ranelate, we added a short explanation about its mechanism of action: "In particular, SrRan has been shown to enhance preosteoblastic cell replication and osteoblastic differentiation and to decrease abilities of osteoblasts to induce osteoclastogenesis, both through the calcium-sensing receptor and an increase in the OPG/RANKL ratio (new reference: Brennan TC, Rybchyn MS, Green W, Atwa S, Conigrave $A D$, Mason RS. Osteoblasts play key roles in the mechanisms of action of strontium ranelate. Br J Pharmacol. 2009; 157(7): 1291-1300)".

In the conclusions, the sentence "Dual-energy X-ray Absorptiometry allows to evaluate bone density around hip or knee prosthesis, and further data may be provided by the new Bone Microarchitecture Analysis device." was added after the second paragraph.

\section{See referee reports}

\section{Introduction}

Endosseous implantation is one of the most common procedures in orthopedics and dentistry. The ever expanding aging population has also led to an increasing need for total joint replacements ${ }^{1}$. Unfortunately, the introduction of a prosthesis or a dental implant inevitably alters the physiological transmission of loads to the surrounding bone, which starts a remodeling process, resulting in reduction in bone mineral density (BMD) ${ }^{2}$.

Aseptic loosening due to bone destruction around the prosthesis has been established as the main cause of implant failure ${ }^{3-6}$. Mechanical, thermal and chemical intraoperative damage induces necrotic phenomena on the periprosthetic bone, which takes approximately 3 months to repair ${ }^{2,7}$. Then the osteocytes, acting as mechanoreceptors, translate the mechanical stimulus into an electrical signal, either activating osteoclasts (OCs) in bone areas no longer subjected to physiological loading or stimulating osteoblastic cell lines where bone is stressed, with consequent hypertrophy ${ }^{2,8-10}$.

Despite being a widespread practice, joint arthroplasty almost unavoidably involves a loss of surrounding bone, which can cause periprosthetic fractures resulting in reduced function, subsequent morbidity and increased risk of mortality ${ }^{11}$. After Total Hip Arthroplasty (THA), for example, periprosthetic fractures occur in $0.8 \%$ of patients at 5 years, and $3.5 \%$ at 10 years ${ }^{11,12}$. This is the third most common reason for re-operation ${ }^{13,14}$, while implant failure by aseptic loosening could be expected in $3-10 \%$ of cases within 15 years $^{11,12}$.
A better understanding of the biological basis of peri-implant osteolysis has allowed the development of therapeutic strategies to prevent periprosthetic bone loss, in particular with Bisphosphonates (BPs) and Strontium Ranelate (SrRan).

This paper will cover the biological basis of periprosthetic bone resorption, diagnostic techniques and preventive or therapeutic approaches, both from a pharmacological and surgical point of view.

\section{Pathogenic mechanisms underlying aseptic loosening of implants}

Risk factors for periprosthetic bone destruction include osteoporosis, rheumatoid arthritis, revision surgery and stress shielding. These lead to a resorption process in bone areas that are no longer mechanically subjected ${ }^{15}$. The basis of this process includes mechanical and biological factors ${ }^{16}$.

Several reports have shown that the cellular responses to biomaterial wear particles play an important role ${ }^{16}$. Particles ranging from 0.2 to $10 \mu \mathrm{m}$ in diameter undergo phagocytosis by macrophages ${ }^{17}$.

In vitro studies of macrophage cultures clearly indicate that smaller particles of polymethylmethacrylate (PMMA) and polyethylene, materials used in implants, $(<20 \mu \mathrm{m})$ elicit a significantly increased inflammatory cytokine response, as indicated by increased release of Tumor Necrosis Factor (TNF), IL-1, IL-6, prostaglandin (PG)E2, matrix metalloproteinases, receptor activator of nuclear factor kappaB ligand (RANKL) and other factors that affect osteoclast differentiation and activity ${ }^{16,18-21}$. Moreover, direct biologic interaction between particles and the cell surface is sufficient to activate osteoclastogenic signaling pathways ${ }^{16,18,22}$, causing bone resorption and periprosthetic BMD loss.

Bone turnover markers, due to their high intra-individual variability, have a limited predictive value concerning the extent of periprosthetic bone loss ${ }^{23}$. However, the immediate high postoperative activity of osteoclasts is confirmed by a study on 53 patients followed for 12 months after THA with a cemented femoral $\mathrm{stem}^{23}$. The study showed an early postoperative increase of C-terminal telopeptides of type I collagen (CTX-I) (markers of bone resorption), where the highest level was noted $(+21 \%) 3$ weeks after THA, then decreased at 8 weeks after THA (-7\% from preoperative levels). This increase was significantly correlated with the bone loss measured by DXA in the calcar region ${ }^{23}$. These data suggest that a postoperative antiresorptive treatment administered for the period of increased CTX-I levels could prevent periprosthetic bone loss ${ }^{23}$.

Stress shielding is also considered as a potent stimulator of bone resorption. After a total hip arthroplasty, the stem geometry of the implant plays a key role in the load transfer to the femur and consequently in femoral remodeling ${ }^{24,25}$.

Conflicting results have emerged regarding the hypothesis that the amount of periprosthetic bone remodeling can be influenced by different factors, including sex, age, weight, Body Mass Index (BMI) and bone mass ${ }^{26-30}$. The data on the role of stem design are more consistent ${ }^{24}$. 


\section{Imaging techniques for the evaluation of periprosthetic BMD loss \\ DXA}

Dual-energy X-ray Absorptiometry (DXA) is considered the most reliable tool to evaluate bone remodeling after THA using implants with different stem designs ${ }^{31,32}$. It is also used to assess the effectiveness of these treatments by comparing the medium-term bone density changes between treated and untreated groups. A special piece of software named "metal-removal" enables DXA to analyze periprosthetic bone using seven conventional Regions Of Interest (ROI) called Gruen zones (Figure 1) ${ }^{33,34}$.

Thanks to improvements in software and technology, bone densitometry examinations by DXA may actually allow the detection of periprosthetic bone remodeling that cannot be observed in conventional radiographs as DXA provides an accurate measurement of total and regional periprosthetic BMD after $\mathrm{THA}^{24,35-38}$.

DXA scanning is usually performed with the patient in the supine position, the leg placed in a standardized support to ensure a neutral position ${ }^{38}$. Analysis of the 7 periprosthetic Gruen zones is the most commonly used protocol to evaluate bone remodeling after the implantation of conventional femoral stems $s^{24,31,40,41}$. As shown in Figure 1, in the horizontal plane, the tip of the lesser trochanter

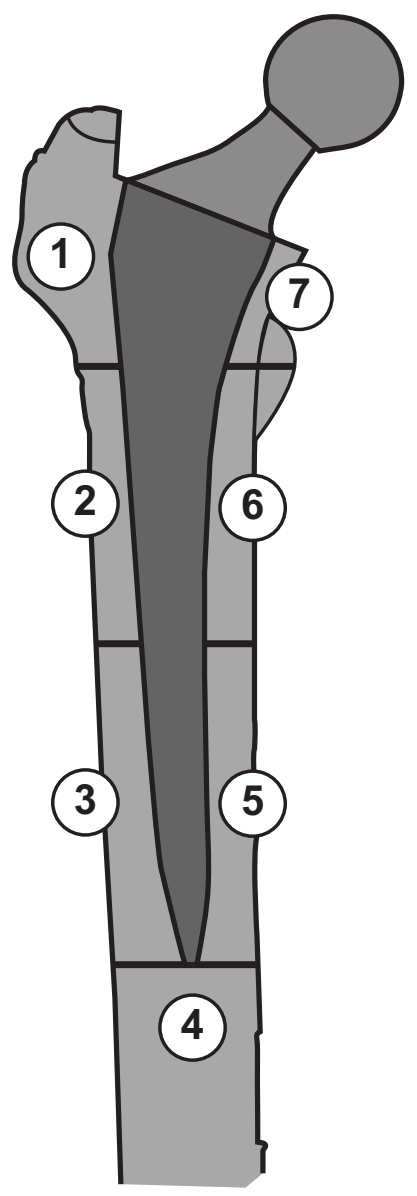

Figure 1. The seven Gruen zones: a model for the evaluation of hip periprosthetic bone remodeling. defines the distal border of zones 1 and 7 . The midpoint between the lesser trochanter and the tip of the stem defines the border between zone 2 and zones 3, 5 and 6 . Zone 4 represents the total bone area $20 \mathrm{~mm}$ distally from the tip of the stem. Vertically, the center axis of the femur divides the medial and lateral zones ${ }^{39}$.

Postoperative measurements are commonly used as baseline values and the measurements at follow-up are expressed as a percentage of the baseline measurements ${ }^{39,42}$. However, in cross-sectional studies, the controlateral unoperated hip has also been analyzed to obtain individual comparative BMD values ${ }^{24,40,43,44}$.

Although DXA is regarded as the most accurate method for the detection of small alterations in bone mineral density around hip prostheses $^{39}$, its metal-removal software also provides peri-prosthetic measurements for knee arthroplasty ${ }^{30,45-49}$. No DXA protocol is available for ankles, shoulders, elbows, or wrists.

\section{X-ray CT imaging with metal subtraction}

The study of periprosthetic bone by X-ray techniques can be hindered by artefacts due to the presence of inorganic material in the scan plane. Metal artefacts can be reduced by the use of suitable filters acting during the acquisition, which allow reducing the radiation spectrum and the dynamic range from the beam itself. There are also algorithms to estimate the error due to the presence of artifacts in the acquired images. A method of suppression of high-density artefacts not requiring the introduction of extra bone artefacts was described by Wey and colleagues ${ }^{47}$. Bone pixels are isolated and segmented by thresholding, then artificial numbers are assigned to them, while the projection profile of metal object is removed ${ }^{47}$.

The effects of femoral adaptive bone remodeling after THA have also been assessed by quantitative computer-tomography assisted osteodensitometry, a method able to differentiate cortical and cancellous bone structures ${ }^{48}$. The CT scans were downloaded onto a dedicated software (CAPPA postOP, CAS Innovations AG, Erlangen, Germany), and automatically evaluated on the basis of an adaptive tracer algorithm that outlined the contour of the outer and inner cortical bone as well as the prostheses, completed by manual correction of metal artefacts ${ }^{48}$.

Moreover, an artifact reduction algorithm was developed in ${ }^{18} \mathrm{~F}-\mathrm{FDG}$ studies by PET/CT scanners ${ }^{49}$. This method, which allows the anatomical information from $\mathrm{CT}$ to be combined with metabolic PET data, is particularly useful in cancer staging, where the improvement in detectability of small lesions located near metal hip implants by this algorithm is very important ${ }^{49}$.

\section{Bone Microarchitecture Analysis (BMA)}

An innovative device has recently been developed, the BMA, which combines ultrahigh resolution 2D digital X-Ray images and a set of trabecular bone texture analysis parameters, such as 2D fractal analysis (H mean), Co-Occurrence (COOC) and Run Length Encoding (RLE), thus providing a bone microarchitecture quantification independent of bone density measurement ${ }^{50}$.

With a resolution near $100 \mu \mathrm{m}$, BMA visualizes the bone structure at the trabecular level, allowing the in vivo micro-analysis of human 
bone structure and abnormalities, such as fracture lines that are often uncertain or ignored. All the joints can be examined (i.e. spine, hip, knee, ankle, shoulder, elbow, wrist and phalanges). The micrometric accuracy in the visualization of joint interspace reflects cartilage thickness, useful for the diagnosis and follow-up of osteoarthritis (OA). The digital X-Ray detector allows examination at a very low dose (effective dose $<2 \mu \mathrm{SV}$ for a heel exam) due to its excellent Detection Quantum Efficiency (DQE). This performance, added to the quality of a high frequency X-Ray generator, is obtained in less than 1 second exposure time, while the image processing is achieved in less than 2 minutes, facilitating patient workflow and improving productivity ${ }^{50}$.

Although not currently widespread, except in few research centers specialized in bone diseases, the employment of BMA may represent a promising device for the study of periprosthetic bone analysis of any joint as well as for arthritis, osteoarthritis and altered bone healing.

\section{Therapeutic strategies for enhancing bone mass recovery after arthroplasty \\ Surgical approaches}

Since the stem geometry of the implant is believed to play an important role in load transfer to the femur, biomechanical tests ${ }^{51-53}$ and radiographic studies ${ }^{54}$, followed by DXA analyses, have been conducted on patients subjected to THA. These studies suggest that the ultra-short implant (which has a more anatomical proximal fit without having a diaphyseal stem with distal cortical contact) can provide immediate postoperative stability and a more physiological load distribution, thus increasing periprosthetic BMD in the medial regions over time ${ }^{24}$, preserving bone mass and stimulating trabecular bone apposition ${ }^{24,53,55}$. The presence of the lateral flare makes the diaphyseal stem with distal cortical contact almost unnecessary, thus increasing periprosthetic BMD in the medial regions over time $^{24}$.

Albanese and colleagues ${ }^{24}$ assessed bone remodeling in patients subjected to two metaphyseal implants, type 1 with a very short stem and type 2 with no diaphyseal stem. Using a 5-ROI protocol of DXA analysis, they found that ultra-short implants can provide immediate postoperative stability and a more natural physiological load distribution in comparison with conventional anatomic implants, thus increasing periprosthetic BMD in the medial regions over time.

After stem design, the most important factor known to influence periprosthetic BMD is the fixation of the implant ${ }^{27}$. A fundamental feature that enables fixation is the porous surface of the prosthesis ${ }^{56}$. Cementless THA is increasingly popular. The high rate of osteolysis, aseptic loosening and revision associated with earlier uncemented femoral components has been greatly reduced by using better designed implants incorporating circumferential porous coating $^{56}$. Moreover, proximal femoral fixation has been shown to prevent stress shielding and a tapered distal tip reduces thigh pain $^{56}$. The mid-term outcome of a modular, cementless, proximally hydroxyapatite-coated, anatomic femoral stem in THA was reported by Cossetto and Goudar (Modulaire Biconique Anatomique, MBA Groupe Lépine, France) ${ }^{56}$. They showed that the modularity of the neck of this femoral component is helpful in both primary and revision settings. In primary procedures, after implantation of the stem, correction can still be made in leg length and offset. In revision procedures, the modularity of the neck facilitates adjustments in leg length, offset and neck version without the need to extract a well fixed femoral component. It also facilitates access to the acetabular component by way of removal of the modular neck and head ${ }^{56}$. In that study, in case of dislocation, changing the modular neck and head avoided more extensive revision requiring removal of a well-fixed femoral stem. Patients were evaluated pre- and postoperatively (at 6 weeks, 3 months, one year, 2 years, 5 years and 10 years), with a clinical evaluation (pain, range of movement, and ability to walk) based on Merle d'Aubigne and Postel scores ${ }^{57}$ and by anteroposterior and lateral weight-bearing radiographs, in which the femoral component was analyzed according to the 7 zones of Gruen. Contrary to the increased rate of revision in modular hip systems found in the Australian Orthopaedic Association National Joint Replacement Registry, the modular, cementless, proximally hydroxyapatite-coated, anatomic femoral stem provided predictably stable fixation with excellent mid-term outcome ${ }^{58}$.

Similarly, Lerch and colleagues ${ }^{33}$ conducted a prospective densitometric study by DXA in a group of patients who underwent unilateral bicontact stem implantation. This is a cementless implant made of a titanium forged alloy (Ti6A14V), with a proximal microporous pure titanium plasmapore coating. Despite small signs of stress shielding observed at the tip of the stem, it has shown to provide adequate proximal bone stock preservation ${ }^{33}$.

Studying knee arthroplasty is rather difficult when compared to studying THA, due to the position of the patient required for the exam. Full extension of the knee is not possible for most patients in the first days after surgery, therefore while deficits in extension normalize with rehabilitation, individual knee flexion between the baseline and follow-up investigations may be different ${ }^{47}$. A clinically applicable soft foam positioner designed to ensure rotational stability and allow for slight flexion (i.e. $25^{\circ}$ ) may be safe for clinical use, because this position can be obtained with all normal total knee arthroplasty (TKA) patients both in the early period after surgery and in later follow-ups ${ }^{47}$.

However, a prospective cohort study conducted by Windisch and colleagues $^{48}$ described the changes in bone density over the course of time following a cement-free TKA based on a functional categorization of the measurements in terms of defined ROI by means of DXA. The seven regions were defined as indicated in Table 1.

A further aim of that study was to examine the associations between the defined parameters of age, sex, severity of arthrosis, and axis alignment. At 12 months after surgery, a high severity of osteoporosis was associated with low absolute values for periprosthetic bone density. Women demonstrated a lower absolute periprosthetic 
Table 1. Seven Regions of Interest (ROI) for bone mineral density measurements after total knee arthroplasty ${ }^{48}$.

\begin{tabular}{lll}
\hline ROI 1 & Distal femoral region above the prosthesis \\
\hline ROI 2 & Lateral proximal region below the tibial prosthesis tray \\
ROI 3 & Lateral distal region below the tibial prosthesis tray \\
\hline ROI 4 & Medial proximal region below the tibial prosthesis tray \\
\hline ROI 5 & Medial distal region below the tibial prosthesis tray \\
\hline ROI 6 & Zone adjacent to the prosthesis below the tibial stem \\
\hline ROI 7 & Distal tibial region below the prosthesis \\
\hline
\end{tabular}

BMD value than men. The preoperatively determined femur and tibial average Cortical bone Marrow Index (CMI), the varus angle and the BMI showed no significant correlation with the absolute or relative changes of periprosthetic bone density ${ }^{48}$. Statistical analysis revealed that the most significant changes occurred within the first 3 months postoperative with the highest bone density loss found in the region of the proximal medial tibia ${ }^{48}$.

Another group ${ }^{49}$ has studied the effects of Unicompartmental Knee Arthroplasty (UKA), which has received renewed interest for medial OA within the last decade. UKA has been traditionally used in older, non-obese patients with a sedentary lifestyle. UKA is advantageous as only the severely damaged compartment is replaced and the bone stock is preserved, which is associated with fast recovery times $^{49}$. Moreover, improvements in surgical technique, implant materials and prosthetic design have made UKAs more durable and reliable ${ }^{49}$.

The group measured BMD using DXA and data were collected from multiple ROIs for each patient at several intervals during the first 7 postoperative days. The highest femoral periprosthetic bone loss rate was observed during the first 3 months after UKA. However, BMD changes from 2-7 years were not significant. In particular, there was a significant loss of BMD from distal femoral sites after UKA, while BMD changes were minor in the tibial metaphyseal regions, consistent with a mechanical axis balance between the medial and lateral sides of the tibia. Further, porous tantalum tibial components maintained better periprosthetic BMD compared with cemented tibial implants ${ }^{49,59}$.

\section{Pharmacological strategies to prevent aseptic loosening}

In combination with improvements in implant integration, strategies to target the cellular components (osteoblasts and osteoclasts) that contribute to implant failure should be implemented ${ }^{60}$. In this regard, it should be noted that differentiation of bone marrow macrophages into mature osteoclasts requires recognition and binding of osteoblasts, fibroblasts, and T cell secreted factor RANKL by its cognate receptor RANK, which is expressed on the surface of osteoclast precursors $^{61-63}$. Another osteoblastic factor, namely osteoprotegerin (OPG), acts as a decoy receptor by binding to RANKL and reducing its bioavailability. On the other hand, binding of RANKL to RANK stimulates induction of several intracellular pathways by this receptor, leading to activation of key transcription factors, most notably NF- $\kappa \mathrm{B}^{22}$.

It is known that NF- $\kappa \mathrm{B}$ activation, when induced by factors such as TNF and PMMA particles, exacerbates osteoclastogenesis and inflammatory responses ${ }^{22}$. In this context, a review by the group of Abu-Amer considers three kinds of approaches ${ }^{22}$. The first involves targeting OC precursor cells, which are brought to inflammatory sites by circulating cytokines. The second entails targeting precursors that are stimulated by the particle-mediated cellular response to differentiate into OCs. The third approach involves targeting activation mechanisms of mature osteoclasts ${ }^{22}$.

An example of the first strategy is the application of RANKL decoy molecules such as OPG and the soluble fusion protein RANK$\mathrm{Fc}^{64,65}$, but the successful preclinical findings, i.e. the ability to prevent and reverse wear debris-induced osteolysis, have not been confirmed by clinical trials. At present, the monoclonal antibody anti-RANKL is available, known as 'denosumab', which shows significant effectiveness in the inhibition of bone resorption due to osteoporosis ${ }^{66}$. Transduction of a dominant-negative form of the $\mathrm{NF}-\kappa \mathrm{B}$ inhibitory protein, $\mathrm{I} \kappa \mathrm{B}$, by retaining NF- $\kappa \mathrm{B}$ in the cytoplasm, has been revealed to be able to block osteoclast formation and activity ${ }^{16,67-69}$. Another viable approach is to block activation of the upstream IKK complex, which is responsible for phosphorylation of $\mathrm{I} \kappa \mathrm{B}$ and subsequent activation of $\mathrm{NF}-\kappa \mathrm{B}$, by introducing a small peptide that hinders assembly of the IKK complex ${ }^{16,70}$. Notably, administration of the dominant negative I $\mathrm{B}$ protein or the IKK inhibitory small peptide to arthritic mice blocks bone erosion and particle-induced osteolysis of calvaria in mice ${ }^{16,71}$.

Further targets of therapy are NF- $\mathrm{BB}$ mediated genes. Recent studies have revealed that proinflammatory cytokines such as TNF act directly on some of these genes and their products, in particular $\mathrm{c}-\mathrm{src}$ and NF- $\mathrm{BB}$, to accelerate osteoclast formation and cause a strong osteoclastic response ${ }^{71}$. Selective inhibitors of the c-src tyrosine kinase have shown great promise in reducing osteoclast activity ${ }^{16,72,73}$.

Another promising approach involves the use of bisphosphonates $(\mathrm{BP})^{2,16,74}$, potent anti-resorptive drugs widely used in the treatment of osteoporosis, which inhibit osteoclast function and induce their apoptosis. In animal models subjected to implantation ${ }^{75-77}$, oral BP showed reduced radiographic periprosthetic radiolucency, as inhibiting debris-induced osteolysis, although the levels of PGE2 and IL-1 remained elevated in tissue cultures from these implants. These studies have served as a basis for clinical trials using alendronate, one of the most commonly used BPs, in patients with radiographically evident osteolytic lesions. In other studies, bone loss around implants was prevented and treated by alendronate ${ }^{78-81}$.

More recently, human clinical trials have revealed the efficacy of BPs in reducing particle-induced osteolysis over the first year of life of cemented and cementless hip and knee replacement prostheses, with better and more durable results when treatment was started early after surgery and continued for over 6 months $s^{2,82,83}$. Moreover, in vivo trials showed a direct action of some BPs in stimulating the osteoblastic proliferation, which might play an essential role in 
increasing periprosthetic bone ingrowth ${ }^{84}$. The mechanism by which BPs are supposed to act on the osteoblasts is by up-regulating the expression of genes coding the synthesis of some morphogenetic proteins, including BMP- $2^{85}$.

Muratore and colleagues assessed the effect of ibandronate, another type of BP that can peculiarly be administered either orally or intravenously, with extended dosing intervals, thanks to its high affinity for the bone mineral component and its consequent long-term persistence in the skeletal tissue, which therefore ensures excellent adherence to therapy ${ }^{2}$. Thirty-five women over 60 years old, not necessarily suffering from osteoporosis, were subjected to THA. They were examined by DXA at the $15^{\text {th }}$ day after surgery (T0) and at 6 and 12 months, either at the spine, contralateral femur or periprosthetic femur, both totally and at the 7 Gruen regions. Of these patients, 19 patients received $3 \mathrm{mg}$ ibandronate intravenously within 5 days after surgery and then passed to oral administration with a monthly dose of $150 \mathrm{mg}$, plus calcium carbonate $(1 \mathrm{~g})$ and cholecalciferol (880 IU) supplementation. The other 16 patients formed the control group and were treated only with calcium carbonate $(1 \mathrm{~g})$ and cholecalciferol (880 IU) supplementation. As a result, a reduction in the BMD was observed over the first 6 months from T0 in both groups; smaller reductions were observed in the treated group ( $-7.7 \%$ compared to the control group). In contrast, at 12 months, a marked trend reversal was observed, with a statistically significant BMD percentage recovery compared to the baseline value at $\mathrm{T} 0$ of about $1.74 \%$ of the global BMD in the treatment group. This was more evident in region $\mathrm{R} 1(+3.81 \%)$ and in the lateral metaphyseal region $(\mathrm{R} 2)(+4.12 \%)$. On the other hand, no global BMD recovery was observed in the control group, which had virtually stabilized compared to values at 6 months $^{2}$.

Considering that periprosthetic remodeling occurs within the first 6-12 months after surgery, this study therefore concluded that ibandronate reduces periprosthetic resorption, in particular in the medial metaphyseal region (calcar and lesser trochanter), the one at greater risk with respect to the life of the prosthesis.

Bisphosphonates, which are chemically stable analogues of inorganic pyrophosphate, can be classified into at least two groups with different molecular modes of action. The simpler non-nitrogencontaining bisphosphonates (such as etidronate and clodronate, BPs of first generation) can be metabolically incorporated into nonhydrolysable analogues of adenosine triphosphate, which interfere with adenosine triphosphate-dependent intracellular pathways ${ }^{86}$. The more potent nitrogen-containing bisphosphonates (including pamidronate, alendronate, risedronate, ibandronate, and zoledronate) are not metabolized in this way but inhibit key enzymes of the mevalonate/cholesterol biosynthetic pathway, such as farnesyl pyrophosphate synthase, compromising the function of essential intracellular messengers, thus causing osteoclast inactivation and apoptosis $^{87}$.

A meta-analysis ${ }^{11}$ of 14 randomized controlled trials employing BPs after joint arthroplasty found that the protective effect of these drugs, probably modified by BP generation and the prosthesis location, could persist in a middle-term follow-up after surgery and for 18 to 70 months after drug discontinuation. The efficacy was more potent for amino-BPs, than for the first generation of BPs ${ }^{11}$.

However, since the trials did not address the clinically relevant outcomes, it is imperative to perform a randomized clinical trial with an adequate number of patients and sound methodology in order to establish the definitive role of BPs in joint arthroplasty, and make recommendations for their optimal administration. It is also necessary to better understand the mechanisms of their actions and potential side effects ${ }^{11}$.

Moreover, prolonged use of BPs has recently been associated with severe suppression of bone turnover ${ }^{8-90}$, alterations in normal collagen cross-linking and matrix heterogeneity ${ }^{91-93}$, reduced vascularity ${ }^{94,95}$ and decreased cortical bone toughness ${ }^{95-98}$, as well as a small number of subtrochanteric or diaphyseal femoral fractures ${ }^{95,99-102}$. The exact mechanism of these 'atypical' fractures is unknown. One theory is that they occur in the subtrochanteric region of the femur because it is subject to high bending forces ${ }^{103-106}$. The latter would cause the formation of micro-cracks, normally repaired through bone remodeling. Bisphosphonates' suppression of bone turnover results in a failure to repair these micro-cracks ${ }^{102}$.

Calcitonin is a 32-amino acid polypeptide hormone (produced predominantly in C-cells of the thyroid gland) which mainly acts by inhibiting osteoclast function ${ }^{107}$. It has been shown that $200 \mathrm{IU}$ of salmon calcitonin administered nasally decreases osteoporotic fractures $^{108,109}$. A Finnish clinical trial ${ }^{107}$ randomized 60 patients who underwent THA using cemented Exeter prostheses into a treatment group (200 IU salmon calcitonin + calcium $500 \mathrm{mg}$ ) and placebo group (inactive nasal spray + calcium $500 \mathrm{mg}$ ) for 6 months. They were followed with DXA, bone turnover markers and dynamic histomorphometry on bone biopsies taken from the femoral neck at the time of discharge, after 6 and 12 months. Calcitonin was not shown to promote any additional value on calcium substitution in preventing aseptic osteolysis ${ }^{107}$.

Another antiosteoporotic treatment, Strontium Ranelate (SrRan), was shown to be of considerable interest in investigations to improve implant osseointegration ${ }^{1}$. The beneficial effects of SrRan have previously been reported in various animal models, where it has been shown to prevent bone loss by maintaining bone formation at a high level and inhibiting bone resorption ${ }^{1,110-114}$. These in vivo results were consistent with in vitro data which show that SrRan reduces bone resorption by osteoclasts and increases bone formation by osteoblasts ${ }^{115-118}$. In particular, SrRan has been shown to enhance preosteoblastic cell replication and osteoblastic differentiation and to decrease abilities of osteoblasts to induce osteoclastogenesis, both through the calcium-sensing receptor and an increase in the OPG/RANKL ratio ${ }^{116-118}$.

It has also been demonstrated that SrRan is able to improve bone biomechanical and structural properties ${ }^{119}$. Furthermore, treatment with SrRan is not associated either with osteonecrosis of the jaw or with low energy atypical fractures of the femur ${ }^{1}$. 
A group from the Bone Division of Geneva ${ }^{1}$ showed that SrRan significantly improves mechanical fixation of titanium implants inserted into the tibias of female rats, with both a positive effect on bone microarchitecture and on bone biomaterial properties in the vicinity of the implant. SrRan increased pull-out strength compared to controls $(+34 \%)$, with a significant improvement of bone microarchitecture around the implant, a more plate-shape structure and an increase in bone-to-implant contact $(+19 \%)^{1}$.

Another study ${ }^{120}$ was designed to evaluate the effect of systemic SrRan treatment on fixation of hydroxyapatite (HA)-coated titanium screws in ovariectomized (OVX) rats. The OVX rats were randomly divided into the following groups: OVX (without treatment), OVX+SRL (treated with a low SR (i.e. SrRan) dose of $500 \mathrm{mg} / \mathrm{kg} /$ day) and OVX+SRH (with a high SR dose of $1000 \mathrm{mg} / \mathrm{kg} / \mathrm{day}$ ). Micro-CT and biomechanical push-out tests were performed twelve weeks after treatment, in order to evaluate bone blocks with implants. The two groups treated with SR showed an increase of bone volume ratio, osseointegration and maximal force, compared to OVX animals, suggesting that SrRan treatment can improve HA-coated screw fixation dose-dependently in OVX rats and facilitate the stability of the implant in the osteoporotic bone $\mathrm{e}^{120}$.

These results may support the potential benefits of SrRan in enhancing osseointegration in orthopaedic and dental surgery.

\section{Conclusions}

Aseptic loosening, due to periprosthetic osteolysis, is the most common cause of implant failure.

Among the other clinical and biomechanical criteria, bone status should be considered before proceeding with arthroplasty, in order to select the most adequate implant model as well as to evaluate the necessity of an anti-osteoporosis therapy.
Dual-energy X-ray Absorptiometry allows evaluation of bone density around hip or knee prosthesis, and further data may be provided by the new Bone Microarchitecture Analysis device.

The comprehension of the principal mechanisms of periprosthetic bone loss has led to the development of pharmacologic strategies aiming at the enhancement of bone mass recovery after surgery and consequently to the prolongation of implant survival.

BPs, potent anti-resorptive drugs widely used in the treatment of osteoporosis and other disorders of bone metabolism, were shown to be particularly effective in reducing periprosthetic bone resorption in the first year after hip and knee arthroplasty, both cemented and cementless.

SrRan, due to its antiresorbing and bone-forming activity, also promises to facilitate the stability of dental and joint implants in both healthy and osteoporotic bone.

\section{Author contributions}

LC prepared the first draft of the manuscript. LC and MLB were involved in the revision and have agreed to the final content.

\section{Competing interests}

No competing interests were disclosed.

\section{Grant information}

The author(s) declared that no grants were involved in supporting this work.

\section{Acknowledgments}

The authors are grateful to Marco Postiglione MD, for the English language revision of the paper.
1. Maimoun L, Brennan TC, Badoud I, et al.: Strontium Ranelate improves implant osseointegration. Bone. 2010; 46(5): 1436-41. PubMed Abstract | Publisher Full Text

2. Muratore M, Quarta E, Quarta L, et al.: Ibandronate and cementless total hip arthroplasty: densitometric measurement of periprosthetic bone mass and new therapeutic approach to the prevention of aseptic loosening. Clin Cases Miner Bone Metab. 2012; 9(1): 50-55. PubMed Abstract | Free Full Text

3. Goldring SR, Schiller AL, Roilke M, et al: The synovial-like membrane at the bone-cement interface in loose total hip replacements and its proposed role in bone lysis. J Bone Joint Surg Am. 1983; 65(5): 575-84. PubMed Abstract

4. Harris WH, Schiller AL, Scholler JM, et al: Extensive localized bone resorption in the femur following total hip replacement. J Bone Joint Surg Am. 1976; 58(5): $612-8$.

PubMed Abstract

5. Jasty MJ, Floyd WE 3d, Schiller AL, et al.: Localized osteolysis in stable nonseptic total hip replacement. J Bone Joint Surg Am. 1986; 68(6): 912-9. PubMed Abstract

6. Boynton E, Waddell JP, Morton J, et al.: Aseptic loosening in total hip implants: the role of polyethylene wear debris. Can J Surg. 1991; 34(6): 599-605. PubMed Abstract

7. Massari L, De Rito G, Brunoro A, et al:: II Disodio Clodronato riduce il riassorbimento periprotesico in impianti non cementati nelle fasi precoci: studio prospettico con controllo. GIOT. 2002; 28: 79-87.

Reference Source

8. Iolascon G: Bisfosfonati e protesi articolari. Up-to-date 2005. In: Adami S (Ed.) Bisfosfonati Yearbook. 2005; 71-78.

Reference Source

9. Marotti G, Muglia MA, Palumbo C: Collagen texture and osteocyte distribution in lamellar bone. Ital J Anat Embryol. 1995; 100(Suppl. 1): 95-102. PubMed Abstract

10. Rubinacci A, Villa I, Dondi Benelli F, et al.: Osteocyte-bone lining cell system at the origin of steady ionic current in damaged amphibian bone. Calcif Tissue Int 1998; 63(4): 331-339.

PubMed Abstract | Publisher Full Text

11. Lin T, Yan SG, Cai XZ, et al:: Bisphosphonates for periprosthetic bone loss after joint arthroplasty: a meta-analysis of 14 randomized controlled trials. Osteoporos Int. 2012; 23(6): 1823-1834. PubMed Abstract | Publisher Full Text

12. Furnes $\mathrm{O}$, Lie SA, Espehaug B, et al:: Hip disease and the prognosis of total hip replacements. A review of 53,698 primary total hip replacements reported to the Norwegian Arthroplasty Register 1987-99. J Bone Joint Surg Br. 2001; 83(4) 579-586.

PubMed Abstract | Publisher Full Text

13. Maury AC, Pressman A, Cayen B, et al.: Proximal femoral allograft treatment 
of Vancouver type-B3 periprosthetic femoral fractures after total hip arthroplasty. J Bone Joint Surg Am. 2006; 88(5): 953-958. PubMed Abstract | Publisher Full Text

14. McLean AL, Patton JT, Moran M: Femoral replacement for salvage of periprosthetic fracture around a total hip replacement. Injury: Int J Care Injured. 2012; 43(7): 1166-1169.

PubMed Abstract | Publisher Full Text

15. Demos HA, Briones MS, White PH, et al:: A Biomechanical Comparison of Periprosthetic Femoral Fracture Fixation in Normal and Osteoporotic Cadaveric Bone. J Arthroplasty. 2012; 27(5): 783-8. PubMed Abstract | Publisher Full Text

16. Abu-Amer Y, Darwech I, Clohisy JC: Aseptic loosening of total joint replacements: mechanisms underlying osteolysis and potential therapies. Arthritis Res Ther. 2007; 9(Suppl 1): S6.

PubMed Abstract | Publisher Full Text | Free Full Text

17. Gelb H, Schumacher HR, Cuckler J, et al:: In vivo inflammatory response to polymethylmethacrylate particulate debris: effect of size, morphology, and surface area. J Ortho Res. 1994; 12(1): 83-92.

PubMed Abstract | Publisher Full Text

18. Gonzalez O, Smith RL, Goodman SB: Effect of size, concentration, surface area, and volume of polymethylmethacrylate particles on human macrophages in vitro. J Biomed Mater Res. 1996; 30(4): 463-473.

PubMed Abstract | Publisher Full Text

19. Shanbhag AS, Jacobs JJ, Glant TT, et al.: Composition and morphology of wea debris in failed uncemented total hip replacement. J Bone Joint Surg Br. 1994; 76(1): 60-67.

PubMed Abstract

20. Abbas S, Clohisy JC, Abu-Amer Y: Mitogen-activated protein (MAP) kinase mediate PMMA-induction of osteoclasts. J Orthop Res. 2003; 21(6): 1041-1048. PubMed Abstract | Publisher Full Text

21. O'Keefe RJ, Rosier RN, Teot LA, et al.: Cytokine and matrix metalloproteinase expression in pigmented villonodular synovitis may mediate bone and cartilage destruction. lowa Orthop J. 1998; 18: 26-34.

PubMed Abstract | Free Full Text

22. Gallo J, Kamínek P, Tichá V, et al:: Particle disease. A comprehensive theory of periprosthetic osteolysis: a review. Biomed Pap Med Fac Univ Palacky Olomouc Czech Repub. 2002; 146(2): 21-28.

PubMed Abstract | Publisher Full Text

23. Arabmotlagh M, Sabljic R, Rittmeister M: Changes of the biochemical markers of bone turnover and periprosthetic bone remodeling after cemented hip arthroplasty. J Arthroplasty. 2006; 21(1): 129-34.

PubMed Abstract | Publisher Full Text

24. Albanese CV, Santori FS, Pavan L, et al.: Periprosthetic DXA after total hip arthroplasty with short vs. ultra-short custom-made femoral stems: 37 patients followed for 3 years. Acta Orthop. 2009; 80(3): 291-297. PubMed Abstract | Publisher Full Text | Free Full Text

25. Hua J, Walker PS: Closeness of fit of uncemented stems improves the strain distribution in the femur. J Orthop Res. 1995; 13(3): 339-46. PubMed Abstract

26. Brodner $\mathrm{W}$, Bitzan $\mathrm{P}$, Lomoschitz $\mathrm{F}$, et al:: Changes in bone mineral density in the proximal femur after cementless total hip arthroplasty. A five-year longitudinal study. J Bone Joint Surg Br. 2004; 86(1): 20-6. PubMed Abstract | Publisher Full Text

27. Rahmy Al, Gosens T, Blake GM, et al:: Periprosthetic bone remodeling of two types of uncemented femoral implant with proximal hydroxyapatite coating: a 3-year follow-up study addressing the influence of prosthesis design and preoperative bone density on periprosthetic bone loss. Osteoporos Int. 2004 15(4): 281-9.

PubMed Abstract | Publisher Full Text

28. Korovessis $\mathrm{P}$, Droutsas $\mathrm{P}, \mathrm{Piperos} \mathrm{G}$, et al.: Course of bone mineral content changes around cementless Zweymüller total hip arthroplasty. A 4-year followup study. Arch Orthop Trauma Surg. 1997; 116(1-2): 60-5.

PubMed Abstract | Publisher Full Text

29. Sköldenberg OG, Bodén HS, Salemyr MO, et al:: Periprosthetic proximal bone loss after uncemented hip arthroplasty is related to stem size: DXA measurements in 138 patients followed for 2-7 years. Acta Orthop. 2006; 77(3) 386-92.

PubMed Abstract | Publisher Full Text

30. Kärrholm J, Anderberg C, Snorrason F, et al:: Evaluation of a femoral stem with reduced stiffness. A randomized study with use of radiostereometry and bone densitometry. J Bone Joint Surg Am. 2002; 84-A(9): 1651-8.

PubMed Abstract

31. Panisello JJ, Herrero L, Herrera A, et al:: Bone remodeling after total hip arthroplasty using an uncemented anatomic femoral stem: a three-yea prospective study using bone densitometry. J Orthop Surg (Hong Kong). 2006; 14(1): 32-37.

PubMed Abstract | Publisher Full Text

32. Albanese CV, Rendine M, De alma F, et al:: Bone remodeling in THA: a comparative DXA scan study conventional implants and a new stemless femoral component. A preliminary report. Hip Int. 2006; 16(Suppl 3): 9-15. PubMed Abstract
33. Lerch M, Kurtz A, Windhagen $\mathrm{H}$, et al.: The cementless Bicontact ${ }^{\oplus}$ stem in a prospective dual-energy X-ray absorptiometry study. Int Orthop. (SICOT) 2012; 36(11): 2211-2217.

PubMed Abstract | Publisher Full Text | Free Full Text

34. Gruen TA, McNeice GM, Amstutz HC: "Modes of failure" of cemented stem-type femoral components: a radiographic analysis of loosening. Clin Orthop Relat Res. 1979; (141): 17-27.

PubMed Abstract | Publisher Full Text

35. Trevisan C, Bigoni M, Cherubini R, et al:: Dual X-ray Absorptiometry for the evaluation of bone density from the proximal femur after total hip arthroplasty: analysis, protocols and reproducibility. Calcif Tissue Int. 1993; 53(3): 158-61. PubMed Abstract | Publisher Full Text

36. Mirsky EC, Einhorn TA: Bone densitometry in orthopaedic practice. J Bone Joint Surg Am. 1998; 80(11): 1687-98. PubMed Abstract

37. Spittlehouse AJ, Smith TW, Eastell R: Bone loss around 2 different types of hip prostheses. J Arthroplasty. 1998; 13(4): 422-7. PubMed Abstract | Publisher Full Text

38. Venesmaa PK, Kröger HP, Miettinen $\mathrm{HJ}$, et al: Monitoring of periprosthetic BMD after uncemented total hip arthroplasty with dual-energy X-ray absorptiometry--a 3-year follow-up study. J Bone Min Res. 2001; 16(6): 1056-61. PubMed Abstract | Publisher Full Text

39. Nysted M, Benum P, Klaksvik J, et al: Periprosthetic bone loss after insertion of an uncemented, customized femoral stem and an uncemented anatomical stem. A randomized DXA study with 5-year follow-up. Acta Orthop. 2011; 82(4): $410-416$.

PubMed Abstract | Publisher Full Text | Free Full Text

40. Aldinger PR, Sabo D, Pritsch M, et al.: Pattern of periprosthetic bone remodeling around stable uncemented tapered hip stems: a prospective 84-month followup study and a median 156-month cross-sectional study with DXA. Calcif Tissue Int. 2003; 73(2): 115-21.

PubMed Abstract | Publisher Full Tex

41. Bodén HS, Sköldenberg OG, Salemyr MO, et al:: Continuous bone loss around a tapered uncemented femoral stem. A long-term evaluation with DEXA. Acta Orthop. 2006; 77(6): 877-85.

PubMed Abstract | Publisher Full Text

42. Kobayashi S, Saito N, Horiuchi $\mathrm{H}$, et al.: Poor bone quality or hip structure as risk factors affecting survival of total-hip arthroplasty. Lancet. 2000; 355(9214): 1499-504.

PubMed Abstract | Publisher Full Text

43. Gibbons CE, Davies AJ, Amis AA, et al:: Periprosthetic bone mineral density changes with femoral components of differing design philosophy. Int Orthop. 2001; 25(2): 89-92.

PubMed Abstract | Publisher Full Text | Free Full Text

44. Munting E, Smitz $\mathrm{P}$, Van Sante N, et al:: Effect of a stemless femoral implant for total hip arthroplasty on the bone mineral density of the proximal femur. A prospective longitudinal study. J Arthroplasty. 1997; 12(4): 373-9. PubMed Abstract | Publisher Full Text

45. Hernandez-Vaquero M, Garcia-Sandoval MA, Fernandez-Carreira JM, et al:: Measurement of bone mineral density is possible with standard radiographs: a study involving total knee replacement. Acta Orthop. 2005; 76(6): 791-795. PubMed Abstract | Publisher Full Text

46. Windisch C, Windisch B, Kolb W, et al:: Osteodensitometry measurements of periprosthetic bone using dual energy $\mathrm{X}$-ray absorptiometry following total knee arthroplasty. Arch Orthop Trauma Surg. 2012; 132(11): 1595-1601. PubMed Abstract | Publisher Full Text

47. Wei J, Chen L, Sandison GA, et al:: X-ray CT high density artefact suppression in the presence of bones. Phys Med Biol. 2004; 49(24): 5407-18.

PubMed Abstract | Publisher Full Text

48. Pitto RP, Bhargava A, Pandit S, et al:: Quantitative CT-assisted osteodensitometry of femoral adaptive bone remodelling after uncemented total hip arthroplasty. Int Orthop. 2008; 32(5): 589-95.

PubMed Abstract | Publisher Full Text | Free Full Text

49. Kennedy JA, Israel O, Frenkel A, et al:: The reduction of artifacts due to metal hip implants in CT-attenuation corrected PET images from hybrid PET/CT scanners. Med Biol Eng Comput.. 2007; 45(6): 553-62.

PubMed Abstract | Publisher Full Text

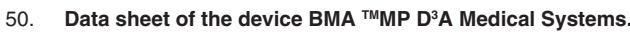
Reference Source

51. Kim YH, Kim JS, Cho SH: Strain distribution in the proximal human femur. An in vitro comparison in the intact femur and after insertion of reference and experimental femoral stems. J Bone Joint Surg Br. 2001; 83(2): 295-301. PubMed Abstract | Publisher Full Text

52. Westphal FM, Bishop N, Püschel K, et al.: Biomechanics of a new shortstemmed uncemented hip prosthesis: an in-vitro study in human bone. Hip Int. 2006; 16(Suppl 3): S22-S30.

PubMed Abstract

53. Walker PS, Culligan SG, Hua J, et al:: The effect of a lateral flare feature on uncemented hip stems. Hip International. 1999; 9: 71-80.

54. Leali A, Fetto J, Insler $\mathrm{H}$, et al.: The effect of a lateral flare feature on implant 
stability. Int Orthop. 2002; 26(3): 166-9.

PubMed Abstract | Publisher Full Text | Free Full Text

55. Leali A, Fetto JF: Preservation of femoral bone mass after total hip replacements with a lateral flare stem. Int Orthop. 2004; 28(3): 151-4. PubMed Abstract | Publisher Full Text | Free Full Text

56. Cossetto DJ, Goudar Al: Mid-term outcome of a modular, cementless, proximally hydroxyapatite-coated, anatomic femoral stem. J Orthop Surg (Hong Kong). 2012; 20(3): 322-6. PubMed Abstract

57. D'Aubigne RM, Postel M: Functional results of hip arthroplasty with acrylic prosthesis. J Bone Joint Surg Am. 1954; 36-A(3): 451-75. PubMed Abstract | Publisher Full Text

58. Australian Orthopaedic Association National Joint Replacement Registry Annual Report. Adelaide: AOA; 2010: 46-50.

59. Minoda $\mathrm{Y}$, Kobayashi $\mathrm{A}$, Iwaki $\mathrm{H}$, et al:: Comparison of bone mineral density between porous tantalum and cemented tibial total knee arthroplasty components. J Bone Joint Surg Am. 2010; 92(3): 700-6. PubMed Abstract | Publisher Full Text

60. Zreiqat $\mathrm{H}$, Crotti TN, Howlett $\mathrm{CR}$, et al.: Prosthetic particles modify the expression of bone-related proteins by human osteoblastic cells in vitro. Biomaterials. 2003; 24(2): 337-346. PubMed Abstract

61. Wei X, Zhang X, Zuscik MJ, et al: Fibroblasts express RANKL and support osteoclastogenesis in a COX-2-dependent manner after stimulation with titanium particles. J Bone Miner Res. 2005; 20(7): 1136-1148. PubMed Abstract | Publisher Full Text

62. Ritchlin CT, Schwarz EM, O'Keefe RJ, et al:: RANK, RANKL and OPG in inflammatory arthritis and periprosthetic osteolysis. J Musculoskelet Neuronal Interact. 2004; 4(3): 276-284. PubMed Abstract

63. Khosla S: Minireview: the OPG/RANKL/RANK system. Endocrinology. 2001; 142(12): 5050-5055.

PubMed Abstract | Publisher Full Text

64. Childs LM, Paschalis EP, Xing L, et al:: In vivo RANK signaling blockade using the receptor activator of NF-kappaB:Fc effectively prevents and ameliorates wear debris-induced osteolysis via osteoclast depletion without inhibiting osteogenesis. J Bone Miner Res. 2002; 17(2): 192-199. PubMed Abstract | Publisher Full Text

65. Ulrich-Vinther M, Carmody EE, Goater JJ, et al:: Recombinant adeno-associated virus-mediated osteoprotegerin gene therapy inhibits wear debris-induced osteolysis. J Bone Joint Surg Am. 2002; 84-A(8): 1405-1412. PubMed Abstract

66. Josse R, Khan A, Ngui D, et al.: Denosumab, a new pharmacotherapy option for postmenopausal osteoporosis. Curr Med Res Opin. 2013; 29(3): 205-16. PubMed Abstract | Publisher Full Text

67. Clohisy JC, Hirayama T, Frazier E, et al:: NF-кB signaling blockade abolishes implant particle-induced osteoclastogenesis. J Orthop Res. 2004; 22(1): 13-20. PubMed Abstract | Publisher Full Text

68. Abbas S, Abu-Amer Y: Dominant-negative IkappaB facilitates apoptosis of osteoclasts by tumor necrosis factor-alpha. J Biol Chem. 2003; 278(22): 20077-20082.

PubMed Abstract | Publisher Full Text

69. Clohisy J, Roy B, Biondo C, et al:: Direct inhibition of NF-kappa B blocks bone erosion associated with inflammatory arthritis. J Immunol. 2003; 171(10): $5547-5553$. PubMed Abstract

70. Dai S, Hirayama T, Abbas S, et al:: The IkappaB kinase (IKK) inhibitor, NEMO binding domain peptide, blocks osteoclastogenesis and bone erosion in inflammatory arthritis. J Biol Chem. 2004; 279(36): 37219-37222. PubMed Abstract | Publisher Full Text

71. Abu-Amer Y: Advances in osteoclast differentiation and function. Curr Drug Targets Immune Endocr Metabol Disord. 2005; 5(3): 347-355. PubMed Abstract

72. Susva M, Missbach M, Green J: Src inhibitors: drugs for the treatment of osteoporosis, cancer or both? Trends Pharmacol Sci. 2000; 21(12): 489-495. PubMed Abstract | Publisher Full Text

73. Violette SM, Guan W, Bartlett C, et al:: Bone-targeted src SH2 inhibitors block src cellular activity and osteoclast-mediated resorption. Bone. 2001; 28(1): 54-64.

PubMed Abstract | Publisher Full Text

74. Goldring SR, Gravallese EM: Bisphosphonates: environmental protection for the joint? Arthritis Rheum. 2004; 50(7): 2044-2047.

PubMed Abstract | Publisher Full Text

75. Sato M, Grasser W: Effects of bisphosphonates on isolated rat osteoclasts as examined by reflected light microscopy. J Bone Miner Res. 1990; 5(1): $31-40$.

PubMed Abstract | Publisher Full Text

76. Carano A, Teitelbaum SL, Konsek JD, et al.: Bisphosphonates directly inhibit the bone resorption activity of isolated avian osteoclasts in vitro. $J$ Clin Invest 1990; 85(2): 456-461.

PubMed Abstract | Publisher Full Text | Free Full Text
77. Purdue PE, Koulouvaris P, Potter HG, et al.: The cellular and molecular biology of periprosthetic osteolysis. Clin Orthop Relat Res. 2007; 454: 251-261. PubMed Abstract | Publisher Full Text

78. Sato M, Grasser W, Endo N, et al.: Bisphosphonate action. Alendronate localization in rat bone and effects on osteoclast ultrastructure. $J$ Clin Invest. 1991; 88(6): 2095-2105.

PubMed Abstract | Publisher Full Text | Free Full Text

79. Seedor JG, Quartuccio HA, Thompson DD: The bisphosphonate alendronate (MK-217) inhibits bone loss due to ovariectomy in rats. J Bone Miner Res. 1991; 6(4): 339-346.

PubMed Abstract | Publisher Full Text

80. Balena R, Toolan BC, Shea M, et al.: The effects of 2-year treatment with the aminobisphosphonate alendronate on bone metabolism, bone histomorphometry, and bone strength in ovariectomized nonhuman primates. J Clin Invest. 1993; 92(6): 2577-2586.

PubMed Abstract | Publisher Full Text | Free Full Text

81. Millett PJ, Allen MJ, Bostrom MP: Effects of alendronate on particle-induced osteolysis in a rat model. J Bone Joint Surg Am. 2002; 84-A(2): 236-249. PubMed Abstract

82. Lyons A: Effects of alendronate in total hip arthroplasty. Proceedings of the South African Orthopaedic Association. J Bone Joint Surg Br. 1999; 81(Suppl 3): 313

83. Wilkinson JM, Eagleton AC, Stockley I, et al.: Effect of pamidronate on bone turnover and implant migration after total hip arthroplasty: a randomized trial. J Orthop Res. 2005; 23(1): 1-8.

PubMed Abstract | Publisher Full Text

84. Im GI, Qureshi SA, Kenney J, et al.: Osteoblast proliferation and maturation by bisphosphonates. Biomaterials. 2004; 25(18): 4105-4115.

PubMed Abstract | Publisher Full Text

85. Iolascon G: Bisfosfonati e protesi articolari. Up-to-date 2005. In: Adami S (Ed.) Bisfosfonati Yearbook. 2005: 71-78.

Reference Source

86. Russell RG: Bisphosphonates: the first 40 years. Bone. 2011; 49(1): 2-19. PubMed Abstract | Publisher Full Text

87. Cavalli L, Brandi ML: Targeted approaches in the treatment of osteoporosis: differential mechanism of action of denosumab and clinical utility. Ther Clin Risk Manag. 2012; 8: 253-266.

PubMed Abstract | Publisher Full Text | Free Full Text

88. Odvina CV, Zerwekh JE, Rao DS, et al.: Severely suppressed bone turnover: a potential complication of alendronate therapy. J Clin Endocrinol Metab. 2005; 90(3): 1294-1301.

PubMed Abstract | Publisher Full Text

89. Somford MP, Draijer FW, Thomassen BJ, et al.: Bilateral fractures of the femur diaphysis in a patient with rheumatoid arthritis on long-term treatment with alendronate: clues to the mechanism of increased bone fragility. $J$ Bone Mine Res. 2009; 24(10): 1736-1740.

PubMed Abstract | Publisher Full Text

90. Aspenberg $\mathrm{P}$, Schilcher J, Fahlgren A: Histology of an undisplaced femoral fatigue fracture in association with bisphosphonate treatment: Frozen bone with remodelling at the crack. Acta Orthop. 2010; 81(4): 460-462. PubMed Abstract | Publisher Full Text | Free Full Text

91. Tang SY, Allen MR, Phipps R, et al.: Changes in non-enzymatic glycation and its association with altered mechanical properties following 1-year treatment with risendronate or alendronate. Osteoporos Int. 2009; 20(6): 887-894. PubMed Abstract | Publisher Full Text | Free Full Text

92. Donnelly E, Meredith DS, Nguyen JT, et al:: Reduced cortical bone compositional heterogeneity with bisphosphonate treatment in postmenopausal women with intertrochanteric and subtrochanteric fractures. J Bone Miner Res. 2012; 27(3): $672-678$.

PubMed Abstract | Publisher Full Text

93. Shane E, Burr D, Ebeling PR, et al.: Atypical subtrochanteric and diaphyseal femoral fractures: report of a task force of the American Society for Bone and Mineral Research. J Bone Miner Res. 2010; 25(11): 2267-2294. PubMed Abstract | Publisher Full Text

94. Wood J, Bonjean K, Ruetz S, et al:: Novel antiangiogenic effects of the bisphosphonate compound zoledronic acid. J Pharmacol Exp Ther. 2002 302(3): 1055-1061.

PubMed Abstract | Publisher Full Text

95. Shane E, Burr D, Ebeling PR, et al:: Atypical subtrochanteric and diaphyseal femoral fractures: report of a task force of the American Society for Bone and Mineral Research. J Bone Miner Res. 2010; 25(11): 2267-2294. PubMed Abstract | Publisher Full Text

96. Allen MR, Reinwald S, Burr DB: Alendronate reduces bone toughness of ribs without significantly increasing microdamage accumulation in dogs following 3 years of daily treatment. Calcif Tissue Int. 2008; 82(5): 354-360.

PubMed Abstract | Publisher Full Text | Free Full Text

97. Burr DB, Diab T, Koivunemi A, et al.: Effects of $\mathbf{1}$ to $\mathbf{3}$ years' treatment with alendronate on mechanical properties of the femoral shaft in a canine model: implications for subtrochanteric femoral fracture risk. J Orthop Res. 2009; 27(10): 1288-1292.

PubMed Abstract | Publisher Full Text | Free Full Text

98. Mashiba $\mathrm{T}$, Hirano $\mathrm{T}$, Turner $\mathrm{CH}$, et al:: Suppressed bone turnover by 
bisphosphonates increases microdamage accumulation and reduces some biomechanical properties in dog rib. J Bone Miner Res. 2000; 15(4): 613-620. PubMed Abstract | Publisher Full Text

99. Thompson RN, Phillips JR, McCauley SH, et al.: Atypical femoral fractures and bisphosphonate treatment: experience in two large United Kingdom teaching hospitals. J Bone Joint Surg Br. 2012; 94-B(3): 385-390. PubMed Abstract | Publisher Full Text

100. Yoon RS, Hwang JS, Beebe KS: Long-term bisphosphonate usage and subtrochanteric insufficiency fractures: a cause for concern? J Bone Joint Surg Br. 2011; 93(10): 1289-1295. PubMed Abstract | Publisher Full Text

101. Das De S, Setiobudi T, Shen L, et al:: A rational approach to management of alendronate-related subtrochanteric fractures. J Bone Joint Surg Br. 2010; 92(5): 679-686. PubMed Abstract | Publisher Full Text

102. Cross MB, Nam D, van der Meulen MC, et al:: A rare case of a bisphosphonateinduced peri-prosthetic femoral fracture. J Bone Joint Surg Br. 2012; 94(7): 994-7. PubMed Abstract | Publisher Full Text

103. Bush LA, Chew FS: Subtrochanteric femoral insufficiency fracture following bisphosphonate therapy for osseous metastases. Radiol Case Rep. 2008; 3(4): 232. Publisher Full Text

104. Sayed-Noor AS, Sjödén GO: Subtrochanteric displaced insufficiency fracture after long-term alendronate therapy--a case report. Acta Orthop. 2008; 79(4): 565-567.

PubMed Abstract | Publisher Full Text

105. Kwek EB, Goh SK, Koh JS, et al: An emerging pattern of subtrochanteric stress fractures: a long-term complication of alendronate therapy? Injury. 2008; 39(2): 224-231.

PubMed Abstract | Publisher Full Text

106. Goh SK, Yang KY, Koh JS, et al:: Subtrochanteric insufficiency fractures in patients on alendronate therapy: a caution. J Bone Joint Surg Br. 2007; 89(3): 349-353.

PubMed Abstract | Publisher Full Text

107. Arnala IO: Salmon calcitonin (MIACALCIC NS $200 \mathrm{IU}$ ) in prevention of bone loss after hip replacement. Scand J Surg. 2012; 101(4): 249-254. PubMed Abstract

108. Azria M, Copp DH, Zanelli JM: 25 years of salmon calcitonin; from synthesis to therapeutic use. Calcif Tissue Int. 1995; 57(6): 405-408. PubMed Abstract | Publisher Full Text

109. Stock JL, Avioli LV, Baylink DJ, et al:: Calcitonin-salmon nasal spray reduces the incidence of new vertebral fractures in postmenopausal women. Three-year interim results of the PROOF study. J Bone Miner Res. 1997; 12: S149.

110. Ammann $P$, Shen $V$, Robin $B$, et al.: Strontium ranelate improves bone resistance by increasing bone mass and improving architecture in intact female rats. J Bone Miner Res. 2004; 19(12): 2012-20.

PubMed Abstract | Publisher Full Text

111. Buehler $\mathrm{J}$, Chappuis $\mathrm{P}$, Saffar $\mathrm{JL}$, et al:: Strontium ranelate inhibits bone resorption while maintaining bone formation in alveolar bone in monkeys (Macaca fascicularis). Bone. 2001; 29(2): 176-9. PubMed Abstract | Publisher Full Text

112. Delannoy $P, B a z o t ~ D$, Marie $P J$ : Long-term treatment with strontium ranelate increases vertebral bone mass without deleterious effect in mice. Metabolism. 2002; 51(7): 906-11. PubMed Abstract | Publisher Full Text

113. Hott $M$, Deloffre $P$, Tsouderos $Y$, et al.: $\mathbf{S 1 2 9 1 1 - 2}$ reduces bone loss induced by short-term immobilization in rats. Bone. 2003; 33(1): 115-23. PubMed Abstract | Publisher Full Text

114. Marie PJ, Hott M, Modrowski D, et al:: An uncoupling agent containing strontium prevents bone loss by depressing bone resorption and maintaining bone formation in estrogen-deficient rats. J Bone Miner Res. 1993; 8(5): 607-15. PubMed Abstract | Publisher Full Text

115. Baron R, Tsouderos $\mathrm{Y}$ : In vitro effects of $\mathbf{S 1 2 9 1 1 - 2}$ on osteoclast function and bone marrow macrophage differentiation. Eur J Pharmacol. 2002; 450(1): $11-7$. PubMed Abstract | Publisher Full Text

116. Canalis $E$, Hott $M$, Deloffre $P$, et al.: The divalent strontium salt $\mathrm{S} 12911$ enhances bone cell replication and bone formation in vitro. Bone. 1996; 18: 517-23. PubMed Abstract

117. Takahashi N, Sasaki T, Tsouderos $\mathrm{Y}$, et al:: S 12911-2 inhibits osteoclastic bone resorption in vitro. J Bone Miner Res. 2003; 18(6): 1082-7. PubMed Abstract | Publisher Full Text

118. Brennan TC, Rybchyn MS, Green W, et al.: Osteoblasts play key roles in the mechanisms of action of strontium ranelate. Br J Pharmacol. 2009; 157(1): 1291-300.

PubMed Abstract | Publisher Full Text | Free Full Text

119. Ammann $\mathrm{P}, \mathrm{Badoud} \mathrm{I}, \mathrm{Barraud} \mathrm{S}$, et al: Strontium ranelate treatment improves trabecular and cortical intrinsic bone tissue quality, a determinant of bone strength. J Bone Miner Res. 2007; 22(9): 1419-25. PubMed Abstract | Publisher Full Text

120. Li Y, Feng G, Gao Y, et al:: Strontium ranelate treatment enhances hydroxyapatitecoated titanium screws fixation in osteoporotic rats. J Orthop Res. 2010; 28(5): 578-82.

PubMed Abstract | Publisher Full Text 


\section{Open Peer Review}

\section{Current Peer Review Status:}

\section{Version 2}

Reviewer Report 15 January 2015

https://doi.org/10.5256/f1000research.4823.r7008

(C) 2015 Purdue P. This is an open access peer review report distributed under the terms of the Creative Commons Attribution License, which permits unrestricted use, distribution, and reproduction in any medium, provided the original work is properly cited.

\section{P Edward Purdue}

Division of Research, Hospital for Special Surgery, New York, NY, USA

This is a nice review that more addresses bone loss directly following TJR as opposed to the consequences of wear driven osteolysis that can initiate many years after surgery. Nevertheless, the discussions on treatment approaches are useful. Adding that denosumab is now entering clinical trials for peri-implant osteolysis (clinicaltrials.gov) might be warranted.

Competing Interests: No competing interests were disclosed.

\section{I confirm that I have read this submission and believe that I have an appropriate level of} expertise to confirm that it is of an acceptable scientific standard.

Reviewer Report 13 August 2014

\section{https://doi.org/10.5256/f1000research.4823.r5158}

(C) 2014 Wong J. This is an open access peer review report distributed under the terms of the Creative Commons Attribution License, which permits unrestricted use, distribution, and reproduction in any medium, provided the original work is properly cited.

\section{Jason K.F. Wong}

Institute of Inflammation and Repair, University of Manchester, Manchester, UK

This review nicely covers the current work in enhancing bone integration with modern implants, however this field will be truly exciting over the next 5-10 years as we will see a vast improvement in device design with biologic materials with rapid prototyping and tissue engineering.

Competing Interests: No competing interests were disclosed. 


\title{
I confirm that I have read this submission and believe that I have an appropriate level of expertise to confirm that it is of an acceptable scientific standard.
}

\section{Version 1}

Reviewer Report 27 May 2014

https://doi.org/10.5256/f1000research.1270.r4886

(C) 2014 Parvizi J. This is an open access peer review report distributed under the terms of the Creative Commons Attribution License, which permits unrestricted use, distribution, and reproduction in any medium, provided the original work is properly cited.

\author{
Javad Parvizi \\ Department of Orthopaedics, Rothman Institute, Thomas Jefferson University Hospital, \\ Philadelphia, PA, USA
}

This is a comprehensive evaluation of periprosthetic bone loss in mostly total hip arthroplasty that is helpful for orthopaedic surgeons. Currently, most orthopaedic surgeons only evaluate bone loss with plain radiographs. Having the knowledge to use DXA and BMA may be helpful in selective cases, although ordering advanced imaging on all patients may not be clinically necessary. Additionally, being able to combat bone loss with therapeutic treatments such as bisphosphonates and strontium ranelate may prove useful in a select patient population for a specified duration of time. Overall, this is a helpful article with cutting edge technology that may be useful for imaging techniques to better evaluate bone loss, and holds potential for evaluating future treatments to prevent and restore bone loss.

Title/Abstract: Both are appropriate

Imaging techniques for the evaluation of periprosthetic BMD loss:

- This should include a section on $x$-ray imaging and CT imaging with metal subtraction. - What is the accessibility of BMA? What type of facilities have this? Are there studies comparing this technology with other imaging techniques with implants?

Therapeutic strategies for enhancing bone mass recovery after arthroplasty:

- Good sections on surgical and pharmacological considerations

- Under "Pharmacological strategies to prevent aseptic loosening," the authors mentioned the use of OPG and the soluble fusion protein RANK-Fc. However, there are no studies presented evaluating this in the setting of implants and only in the osteoporosis model. This may not be an appropriate to mention in this article (in comparison to the dominant negative IKB protein or the IKK inhibitory small peptide, which has been demonstrated to block particle-induced osteolysis).

- It would be helpful to provide the mechanism of action of Strontium Ranelate.

Conclusions: There should be a sentence on imaging, as mentioned in the article. 
Competing Interests: No competing interests were disclosed.

\section{I confirm that I have read this submission and believe that I have an appropriate level of expertise to confirm that it is of an acceptable scientific standard, however I have significant reservations, as outlined above.}

Author Response 27 May 2014

Loredana Cavalli, Dep. of Surgery and Translational Medicine, University of Florence, Italy, Italy

The authors would like to thank the referee for his response.

As regards BMA technique, it is not currently widespread for a clinical use, except in few research centers specialized in bone diseases, like ours at Orthopedic Trauma Center in Florence, Italy. As its entrance is very recent, and its potential applications are very wide, it is not yet available a protocol to compare this technique with other ones for peri-prosthetic bone study. So, at the end of the paragraph Imaging techniques for the evaluation etc., before the last sentence, we would add: "Although not currently widespread, except in few research centers specialized in bone diseases, the employment of BMA..."

About metal subtraction option in X-ray and CT imaging, as it represents a real possibility to correct artifacts, we are preparing a brief paragraph to add: thank you for the suggestion!

OPG and RANK-Fc were the first molecular strategy, so we would cite them, adding the sentence "but the successful preclinical findings, i.e. the ability to prevent and reverse wear debris-induced osteolysis, have not been confirmed by clinical trials".

Regarding Strontium Ranelate, we would add: "In particular, SrRan has been shown to enhance preosteoblastic cell replication and osteoblastic differentiation and to decrease abilities of osteoblasts to induce osteoclastogenesis, both through the calcium-sensing receptor and an increase in the OPG/RANKL ratio (new ref.: Brennan TC, Rybchyn MS, Green W, Atwa S, Conigrave AD, Mason RS. Osteoblasts play key roles in the mechanisms of action of strontium ranelate. Br J Pharmacol. 2009;157(7):1291-1300)."

In the conclusions, the sentence "Dual-energy X-ray Absorptiometry allow to evaluate bone density around hip or knee prosthesis, and further data may be provided by the new device called Bone Microarchitecture Analysis." can be added after the second paragraph.

We will provide a new version of the paper with all these corrections as soon as possible.

Competing Interests: No competing interests were disclosed.

Reviewer Report 20 January 2014

https://doi.org/10.5256/f1000research.1270.r2668 
(C) 2014 Wong J. This is an open access peer review report distributed under the terms of the Creative Commons Attribution License, which permits unrestricted use, distribution, and reproduction in any medium, provided the original work is properly cited.

\section{Jason K.F. Wong}

Institute of Inflammation and Repair, University of Manchester, Manchester, UK

I would like to congratulate Loredana Cavalli and Maria Luisa Brandi on this really quite enjoyable review. For me, I found it quite comprehensive but there were some minor omissions such as the role of electrical charge on bone integration and role of tissue engineering and rapid prototyping on prosthetic design in the future. I would also have liked to have more information from the lessons learnt from failed implants in terms of the pathobiology at the interface. Otherwise it was a good review of the literature and worthy of publication.

Competing Interests: No competing interests were disclosed.

\section{I confirm that I have read this submission and believe that I have an appropriate level of expertise to confirm that it is of an acceptable scientific standard.}

Author Response 27 May 2014

Loredana Cavalli, Dep. of Surgery and Translational Medicine, University of Florence, Italy, Italy

The authors would like to thank the referee for his response.

Competing Interests: No competing interests were disclosed.

The benefits of publishing with F1000Research:

- Your article is published within days, with no editorial bias

- You can publish traditional articles, null/negative results, case reports, data notes and more

- The peer review process is transparent and collaborative

- Your article is indexed in PubMed after passing peer review

- Dedicated customer support at every stage

For pre-submission enquiries, contact research@f1000.com 